\title{
Optimization of Nutritional Factors for Nisin yield Improvement by Lactococcus lactis E15 using Corn Steep Liquor Powder as Nitrogen Source
}

\author{
Zhi-jian $\mathrm{Ni}^{1}$, Ai-bing $\mathrm{Ma}^{1}$, Fei Liu ${ }^{1,2}$ and Xi-qiang Zhu ${ }^{1,2 *}$ \\ ${ }^{1}$ Shandong University, PR China \\ ${ }^{2}$ Shandong Academy of Pharmaceutical Science, PR China
}

Submission: February 02, 2017; Published: February 09, 2017

*Corresponding author: Xi-qiang Zhu, 989 New Lok Street, Shandong Academy of Pharmaceutical Science, High-tech Zone, Jinan, Shandong Province, PR China, China, Tel: 86-053181213080; Fax: 86-053181213083; Email: mars_pharma@163.com

\begin{abstract}
In the present study, corn steep liquor powder (CSLP) was positively investigated as nitrogen source to replace the relatively costly peptone typically used for the production of nisin. Meanwhile the nutritional factors and nisin production in batch fermentation by Lactococcus lactis (L. lactis) E15were optimized using a series of statistical design of experiments and response surface methodology on the basis of the modified fermentation medium (CSLP-M). Results indicated that sucrose, Tween-80 and CSLP were significant factors for nisin production, and the first two had positive effects on bacteriocin production, while the last one was on the contrary. The optimum formula obtained for nisin production was composed of $1.97 \%(\mathrm{w} / \mathrm{v})$ sucrose, $0.89 \%(\mathrm{w} / \mathrm{v})$ CSLP, $1 \%(\mathrm{w} / \mathrm{v})$ yeast extract, $0.5 \%(\mathrm{w} / \mathrm{v}) \mathrm{KH}_{2} \mathrm{PO}_{4}, 0.2 \%(\mathrm{w} / \mathrm{v}) \mathrm{NaCl}$, $0.03 \%(\mathrm{w} / \mathrm{v}) \mathrm{MgSO}_{4} \cdot 7 \mathrm{H}_{2} \mathrm{O}, 0.5 \%(\mathrm{w} / \mathrm{v}) \mathrm{CaCO}_{3}$ and $0.28 \%(\mathrm{w} / \mathrm{v})$ Tween-80 (X3) at $\mathrm{pH}$ 6.8. Under the optimized conditions, nisin titer reached a peak level of $3036 \mathrm{IU} \mathrm{ml}^{-1}$ at $14 \mathrm{~h}$ in batch fermentation, which nearly increased by $52 \%$ compared with that in the initial medium. Besides, the controlled fed-batch fermentation in 1.0-L fermenter was carried out and maximum nisin titer of $5370 \mathrm{IU} \mathrm{ml}^{-1}$ after $16 \mathrm{~h}$ was obtained, which might provide a potential strategy for increasing nisin yield in large-scale industrial production.
\end{abstract}

Keywords: Lactococcus lactis; Nisin production; Corn steep liquor powder; Fermentation; Optimization

\section{Introduction}

Lactococcus lactis, formerly also known as Streptococcus lactis [1], is a Gram-positive, facultatively anaerobe bacterium used extensively in the production of buttermilk and cheeses [2]. Nisin, a primary metabolite produced during the growth of several L. lactis strains, is a polycyclic peptide bacteriocin composed of 34 amino acid residues [3,4]. It has long been viewed as an excellent bio preservative widely used in food industry, primarily in dairy products, meat products, and canned and other processed foods, because of its superior antimicrobial activity, and lack of toxicity and side effects $[5,6]$. In addition, nisin emerges as a promising alternative in medical applications for bacterial infection in humans. It has been confirmed to be an anti-infective therapeutic agent against some inflammations of the skin or mucosa [7-10], especially in the oral cavity [11]. Moreover, a potent vaginal contraceptive has even been developed from nisin for future use in humans [12].

Now the industrial-scale production of nisin is achieved largely through fermentation by L. lactis, which is closely associated with the growth of producer cells. This bioprocess requires a large number of complex nutritional factors that has been well studied previously [13-17], including carbon source, nitrogen source, inorganic salts, etc., but the optimum fermentation conditions varied greatly due to differences in the nutrient compositions, experimental conditions and producer strains. Corn steep liquor powder (CSLP) containing a variety of crude proteins and trace elements is favorable for bacterial growth and its product accumulation [18,19], which could be used as an alternative culture medium to increase nisin production. In our preliminary experiments, the nisin yield of L. lactis E15 was estimated with the substitution of CSLP as nitrogen source, but further optimization is necessary.

Response surface methodology (RSM) is an efficient and economical strategy for screening optimal conditions for desirable responses [20-22]. It consists of a group of mathematical and statistical procedures that can be used to study the relationships between one or more responses and 
multiple independent variables, and generates a mathematical model that can accurately predict desirable responses $[23,24]$. Currently RSM has been successfully applied to optimize the medium composition for nisin production for a natural nisinproducing L. lactis strain in batch and fed-batch fermentation systems $[25,26]$.

To the best of our knowledge, there is no reports on the use of RSM to optimize the main nutritional factors containing CSLP as nitrogen source for nisin production. In this study, the effects of eight factors on nisin production of L. lactis E15 were studied in the modified fermentation medium (CSLP-M) and a sequence of experimental designs were employed to optimize the production of nisin by batch fermentation using CSLP as an alternative culture medium.

\section{Materials and Methods}

\section{Bacterial strains and culture conditions}

In the present study, L. lactis E15, a mutant nisin A producer, was obtained from a nisin-producing strain L. lactis subsp. Lactis ATCC 11454 by treatment with physical and chemical mutagens. L. lactis strain was propagated without aeration and $\mathrm{pH}$ control at $30{ }^{\circ} \mathrm{C}$ in M17 broth (OXOID, UK) supplemented with $0.5 \%$ (w/v) glucose (GM17 medium) in an orbital shaker at $100 \mathrm{rpm}$ [27]. When necessary, L. lactis E15 with high yield of nisin A was selected on selective GM17 containing $500 \mathrm{IU} \mathrm{ml}^{-1}$ additional nisin and $0.004 \%$ sterilized bromocresol purple.

Micrococcus flavus NCIB 8166 was used as a nisin sensitive indicator bacterium in the nisin bioactivity assay and it was grown in Luria-Bertani (LB) broth at $37{ }^{\circ} \mathrm{C}$ with shaking at 200rpm. Prior to nisin bioactivity assay, the LB culture of the indicator bacteria was added into Nutrient Broth (NB) medium composed of $0.8 \%(\mathrm{w} / \mathrm{v})$ tryptone, $0.5 \%(\mathrm{w} / \mathrm{v})$ yeast, $0.5 \%$ (w/v) glucose, $0.5 \%(\mathrm{w} / \mathrm{v}) \mathrm{NaCl}, 0.2 \%(\mathrm{w} / \mathrm{v}) \mathrm{Na}_{2} \mathrm{HPO}_{4}, 1 \%(\mathrm{v} / \mathrm{v})$ Tween-20 and $1.2 \%(\mathrm{w} / \mathrm{v})$ agar at $\mathrm{pH} 7.2$ for plate preparation.

\section{Fermentation Conditions}

The initial fermentation medium was composed of $1.5 \%$ $(\mathrm{w} / \mathrm{v})$ sucrose, $1 \%(\mathrm{w} / \mathrm{v})$ yeast extract, $1 \%(\mathrm{w} / \mathrm{v})$ peptone, $0.5 \%$ $(\mathrm{w} / \mathrm{v}) \mathrm{K}_{2} \mathrm{HPO}_{4}, 0.02 \%(\mathrm{w} / \mathrm{v}) \mathrm{MgSO}_{4} \cdot 7 \mathrm{H}_{2} \mathrm{O}, 0.2 \%(\mathrm{w} / \mathrm{v}) \mathrm{NaCl}$, $0.4 \%(\mathrm{w} / \mathrm{v}) \mathrm{CaCO}_{3}$ and $0.2 \%(\mathrm{w} / \mathrm{v})$ Tween-80 at initial $\mathrm{pH} 6.8$. While CSLP, just as a substitute for peptone, was added into the modified fermentation medium (CSLP-M).

Batch fermentation of L. lactis E15 strain was performed without $\mathrm{pH}$ control and aeration at $30{ }^{\circ} \mathrm{C}$ and a stirring rate of $100 \mathrm{rpm}$ for $20 \mathrm{~h}$ in $250-\mathrm{ml}$ flasks containing $50 \mathrm{ml}$ of a series of different fermentation media. Fed-batch fermentation was carried out in a 1.0-L fermenter (INFORS, Switzerland) containing $800 \mathrm{ml}$ of the final optimal fermentation medium simultaneously added $2 \mathrm{ml} \mathrm{l}^{-1}$ antifoamer at $30{ }^{\circ} \mathrm{C}$ and a stirring rate of $100 \mathrm{rpm}$ for $20 \mathrm{~h}$. Sucrose solution (50\%, w/v) was fed at different time points by a manual control system into the broth to maintain the level of residual sucrose at $5-15 \mathrm{~g} \mathrm{l}^{-1}$ during the entire fermentation. Moreover, $\mathrm{NaOH}$ solution $(22.5 \%$, w/v) was added automatically into the fermenter to maintain a constant $\mathrm{pH}$ by a digital $\mathrm{pH}$ controller when the $\mathrm{pH}$ dropped to a value lower than the set-point of 6.8 due to the by-product of lactic acid. Prior to fermentation, seed culture was cultured twice at $30{ }^{\circ} \mathrm{C}$ for $8-10 \mathrm{~h}$ in GM17 broth and the fresh inoculum $(5 \%, \mathrm{v} / \mathrm{v})$ was inoculated into the above fermentation systems. Samples were collected aseptically every two hours from the fermentation systems for the subsequent analyses.

\section{Experimental Designs}

Previous investigations have shown that the major nutritional components affecting nisin production were sucrose, yeast extract, peptone, $\mathrm{K}_{2} \mathrm{HPO}_{4}, \mathrm{MgSO}_{4} \cdot 7 \mathrm{H}_{2} \mathrm{O}, \mathrm{NaCl}, \mathrm{CaCO}_{3}$ and Tween-80 [13-15,25,26]. CSLP is a cheap and easily available organic nitrogen source in the fermentation industry, which could be used as an alternative medium to increase nisin value. In the preliminary experiments, the CSLP-M medium containing CSLP instead of peptone as nitrogen source was positively examined in Figure 1, but still need further optimization.

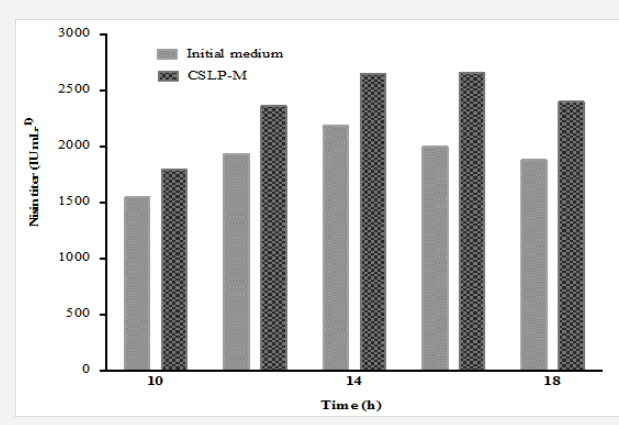

Figure 1: Influence of nitrogen sources on nisin production in the preliminary experiments. Initial medium contains $1 \%$ (w/v) peptone, and CSLP-M medium without peptone, but supplemented with $1 \%(\mathrm{w} / \mathrm{v})$ corn steep liquor powder (CSLP).

\section{Plackett-Burman design (PBD)}

The Plackett-Burman design is a very efficient way for screening the main factors affecting response value among a large number of independent variables. In the present study, a series of experiments were designed to identify the most significant factors of eight variables in the initial formula for nisin production by L. lactis E15, and eight variables were coded according to the following equation:

$$
\mathrm{X}_{\mathrm{i}}=\left(\mathrm{x}_{\mathrm{i}}-\mathrm{x}_{0}\right) / \Delta \mathrm{x}(1),
$$

where $\mathrm{Xi}$ is the coded value of an independent variable, $\mathrm{x}_{\mathrm{i}}$ is the real value of an independent variable, $x_{0}$ is the real value of an independent variable at the center point, and $\Delta \mathrm{x}$ is the step change value. The nisin titer $\left(\mathrm{IUml}^{-1}\right)$ was defined as response value (Y).

\section{Steepest ascent design}

This step was carried out to approach the optimum region of the response value to establish an effective fitted equation 
of the response surface. The direction and change range of the main factors toward predictive higher response values were determined according to the magnitude and sign of linear effect values of various factors $[24,25]$.

\section{Response surface methodology (RSM)}

Response surface methodology (RSM) based on BoxBehnken experimental design (BBD) with three coded levels was adopted to determine the optimal conditions of the screened factors in PBD for improved nisin production. The coded levels of each factor and the design matrix are given in Table 5. The low, middle, and high levels of each variable were designated as $-1,0$, and +1 , respectively.

The whole optimization experiments were executed in $250-\mathrm{ml}$ shake flasks with $50 \mathrm{ml}$ of above designed media. All experiments were repeated for three times.

\section{Analytical Methods}

\section{Residual sucrose concentration determination}

After centrifugation and acid hydrolysis of the fermentation broth, the glucose concentration of the samples was measured by using an SBA Series of Biosensor Analyzer (Biology Institute of Shandong Academy of Science, China) and correlated with sucrose concentration.

\section{Biomass}

The biomass of the fermentation broth was estimated by the optical density at $600 \mathrm{~nm}$ (OD600) using a spectrophotometer (Tecan, Austria) after samples were diluted appropriately.

\section{Lactic acid production}

The production of lactic acid can directly lead to a decline in $\mathrm{pH}$ value offer mentation liquor, so the $\mathrm{pH}$ profiles were measured by using a $\mathrm{pH}$ meter (METTLER TOLEDO, Switzerland) to indirectly indicate the accumulation of lactic acid during the fermentation period.

\section{Nisin bioactivity assay}

Nisin titer was determined by a modified agar diffusion assay according to the method of Kong et al (2014). A standard nisin solution $\left(10^{3} \mathrm{IU} \mathrm{ml}^{-1}\right)$ was prepared by dissolving $0.01 \mathrm{~g}$ of nisin standard $\left(10^{6} \mathrm{IU} \mathrm{g}^{-1}\right.$, Sigma) in $10 \mathrm{ml}$ of $0.02 \mathrm{MHCl}$. Fermentation samples were acidified to $\mathrm{pH} 2.0$ by drop wise adding $2 \mathrm{M} \mathrm{HCl}$ solution to promote the stability and solubility of nisin. Subsequently, the acidified samples $(1 \mathrm{ml})$ were boiled at $100{ }^{\circ} \mathrm{C}$ for $5 \mathrm{~min}$ followed by centrifugation at $12000 \times \mathrm{g}$ for 10 $\min$ at $4{ }^{\circ} \mathrm{C}$. The supernatants were then filtered through a 0.22 $\mu \mathrm{m}$ sterilized membrane filter (Millipore, USA) and stored at $4{ }^{\circ} \mathrm{C}$ until analysis. On the other hand, the testing plate was prepared by pouring $20 \mathrm{ml}$ of molten $\mathrm{NB}$ medium (cooled to $40{ }^{\circ} \mathrm{C}-50$ ${ }^{\circ} \mathrm{C}$ ) pre-mixed with overnight culture of the indicator organism (approx.107CFU ml-1) into sterile plate $(\Phi=90 \mathrm{~mm})$, and allowed to solidify on a horizontal plane at room temperature.
Afterwards, same holes were bored in each agar layer using a sterilized punch, and $100 \mu \mathrm{L}$ of nisin standard solutions with gradient dilution or samples dilutions were added into the wells. After incubation at $37{ }^{\circ} \mathrm{C}$ for $24 \mathrm{~h}$, a standard curve of nisin inhibition zones versus units of nisin standard (Sigma, USA) was drawn by measuring the diameters of inhibition zones caused by nisin standard solution. Accordingly, nisin titer of samples was calculated from this curve. Measurements of all samples were performed in triplicate using three different plates.

\section{Statistical analysis}

The Minitab 17.0 (Minitab Inc, USA) was employed for the experimental designs and subsequent regression analysis of the experimental data obtained [23]. The quality of the regression equations was judged statistically by the coefficient of determination $\mathrm{R}^{2}$, and corresponding statistical significance was determined by a t-test. A value of $\mathrm{p}<0.05$ was considered to be statistically significant.

\section{Results and Discussion}

\section{Plackett-Burman design}

In this step, eight components were defined as different variables, and the concentration for each variable was appropriately enlarged as the ranges in Table 1. Subsequently, 12 experiments were designed to screen the significant factors of eight variables for nisin titer, and the results of the 2-level PBD was illustrated in Table 2, which indicated that there was a wide variation of nisin titer from 1910 to 2906 IUml-1with the different levels of the components in the media.

Table 1: The coded values and levels of defined variables for PlackettBurman design.

\begin{tabular}{|c|c|c|c|}
\hline \multirow{2}{*}{ Factors } & \multirow{2}{*}{$\begin{array}{c}\text { Coded } \\
\text { Variables }\end{array}$} & \multicolumn{2}{|c|}{ Levels (g l-1) } \\
\cline { 3 - 4 } & & 15 & 20 \\
\hline Sucrose & $\mathrm{X} 1$ & 10 & 15 \\
\hline Yeast extract & $\mathrm{X} 2$ & 10 & 15 \\
\hline $\begin{array}{c}\text { corn steep } \\
\text { powder }\end{array}$ & $\mathrm{X} 3$ & 5 & 7.5 \\
\hline $\mathrm{KH}_{2} \mathrm{PO}_{4}$ & $\mathrm{X} 4$ & 0.2 & 0.3 \\
\hline $\mathrm{MgSO}_{4}$ & $\mathrm{X} 5$ & 2 & 3 \\
\hline $\mathrm{NaCl}^{*}$ & $\mathrm{X} 6$ & 4 & 5 \\
\hline $\mathrm{CaCO}_{3}$ & $\mathrm{X} 7$ & 2 & 3 \\
\hline & & & \\
\hline $\mathrm{Tw}^{*}$ & & & \\
\hline
\end{tabular}


Table 2: The design matrix and experimental results of PlackettBurman design with nisin titer as response value $(Y)$

\begin{tabular}{|c|c|c|c|c|c|c|c|c|c|}
\hline Run & $\mathbf{X 1}$ & $\mathbf{X 2}$ & $\mathbf{X 3}$ & $\mathbf{X} 4$ & $\mathbf{X 5}$ & $\mathbf{X 6}$ & $\mathbf{X 7}$ & $\mathbf{X 8}$ & $\begin{array}{c}\mathbf{Y}(\mathbf{I U} \\
\mathbf{m l}-\mathbf{1})\end{array}$ \\
\hline 1 & 1 & -1 & 1 & -1 & -1 & -1 & 1 & 1 & 2586 \\
\hline 2 & 1 & 1 & -1 & 1 & -1 & -1 & -1 & 1 & 2906 \\
\hline 3 & -1 & 1 & 1 & -1 & 1 & -1 & -1 & -1 & 2117 \\
\hline 4 & 1 & -1 & 1 & 1 & -1 & 1 & -1 & -1 & 2212 \\
\hline 5 & 1 & 1 & -1 & 1 & 1 & -1 & 1 & -1 & 2782 \\
\hline 6 & 1 & 1 & 1 & -1 & 1 & 1 & -1 & 1 & 2530 \\
\hline 7 & -1 & 1 & 1 & 1 & -1 & 1 & 1 & -1 & 1910 \\
\hline 8 & -1 & -1 & 1 & 1 & 1 & -1 & 1 & 1 & 2398 \\
\hline 9 & -1 & -1 & -1 & 1 & 1 & 1 & -1 & 1 & 2456 \\
\hline 10 & 1 & -1 & -1 & -1 & 1 & 1 & 1 & -1 & 2803 \\
\hline 11 & -1 & 1 & -1 & -1 & -1 & 1 & 1 & 1 & 2564 \\
\hline 12 & -1 & -1 & -1 & -1 & -1 & -1 & -1 & -1 & 2536 \\
\hline
\end{tabular}

The regression analysis of the PBD of eight factors shown in Table 3 exhibited thatX1 (sucrose, $\mathrm{P}=0.007$ ), $\mathrm{X} 3$ (CSLP, $\mathrm{P}=$ 0.004 ) and $X 8$ (Tween-80, $P=0.03$ ) had the greatest impacts on nisin production at the probability level of $95 \%$. The concentration of sucrose strongly affected nisin production, and the high level of sucrose $(2.25 \%, \mathrm{w} / \mathrm{v})$ allowed the strain to produce a greater nisin titer than the low level of sucrose $(1.5 \%, \mathrm{w} / \mathrm{v})$. It has been considered that sucrose with carbon source have an important influence on nisin biosynthesis due to the genetic linkage between sucrose metabolism and nisin production on the chromosome, and the regulation of carbon metabolism appeared to be a major control mechanism for nisin biosynthesis [13]. Similarly, the high level of X8 (Tween-80) $(0.3 \%, w / v)$ was more beneficial tonisin synthesis. Huot [28] proved that Tween-80 supply could suppress bacteriocin cell adhesion, which was of vital importance for nisin production.

Table 3: The regression analysis of Plackett-Burman design.

\begin{tabular}{|c|c|c|c|c|c|}
\hline Factors & $\begin{array}{c}\text { Effect } \\
\text { Value }\end{array}$ & Coefficient & $\begin{array}{c}\text { Standard } \\
\text { Error }\end{array}$ & T-Value & P-Value \\
\hline Model & & 2482.5 & 22.94 & 108.21 & $0.000^{* * *}$ \\
\hline $\mathrm{X} 1$ & 304.7 & 152.3 & 22.94 & 6.64 & $0.007^{* * *}$ \\
\hline $\mathrm{X} 2$ & -32 & -16 & 22.94 & -0.7 & 0.536 \\
\hline $\mathrm{X} 3$ & -380.7 & -190.3 & 22.94 & -8.3 & $0.004^{* * *}$ \\
\hline $\mathrm{X} 4$ & -80.3 & -40.2 & 22.94 & -1.75 & 0.178 \\
\hline $\mathrm{X} 5$ & 63.7 & 31.8 & 22.94 & 1.39 & 0.259 \\
\hline $\mathrm{X} 6$ & -140 & -70 & 22.94 & -3.05 & $0.055^{*}$ \\
\hline $\mathrm{X} 7$ & 49.3 & 24.7 & 22.94 & 1.08 & 0.361 \\
\hline $\mathrm{X} 8$ & 178.3 & 89.2 & 22.94 & 3.89 & $0.03^{* *}$ \\
\hline
\end{tabular}

Asterisk $\left(^{*}\right)$ indicates the significance level; R2 $=97.96 \%, R 2(\operatorname{adj})=$ $92.52 \%$

In addition, CSLP as a nutritious organic nitrogen source is favorable for bacterial growth and its product accumulation, but nisin production decreased with the enhanced concentration of CSLP in this study, which perhaps due to excessive CSLP would inhibit nisin biosynthesis. Furthermore, the t-value indicated that $\mathrm{X} 5\left(\mathrm{MgSO}_{4} \cdot 7 \mathrm{H}_{2} \mathrm{O}\right)$ and $\mathrm{X} 7\left(\mathrm{CaCO}_{3}\right)$ had positive effects on nisin production and set at their high levels, whereas $\mathrm{X} 2$ (yeast extract), $\mathrm{X} 4\left(\mathrm{~K}_{2} \mathrm{HPO}_{4}\right)$ and $\mathrm{X} 6(\mathrm{NaCl})$ had negative effects and set at their low levels. The regression coefficients were calculated and a fitted equation was obtained as follow:

\section{$\mathrm{Y}=2482.5+152.3 \mathrm{X} 1-16 \mathrm{X} 2-190.3 \mathrm{X} 3-40.2 \mathrm{X} 4+31.8 \mathrm{X} 5$}

$70 \mathrm{X} 6+24.7 \mathrm{X} 7+89.2 \mathrm{X} 8(1)$, where $\mathrm{Y}$ is nisin titer as response value. The coefficient of determination $\mathrm{R}^{2}$ of the model was calculated to be 0.9796 , which means that the model could explain $97.96 \%$ of the variation in the results.

Moreover, the maximal effect was also presented in the upper portion and then decreased progressively to the minimal effect in the Pareto chart (Figure 2), which also showed that the most important factors determining nisin titer were X1 (sucrose), X3 (CSLP) and X8 (Tween-80) at the probability level of 95\% $(\mathrm{P}<0.05)$. Yet, although sucrose, CSLP and Tween-80 were recognized as three significant factors based on the levels of CSLP-M medium, the optimal level of each significant factor was still unknown at this stage. Thus, they need to be determined by the following optimization experiments.

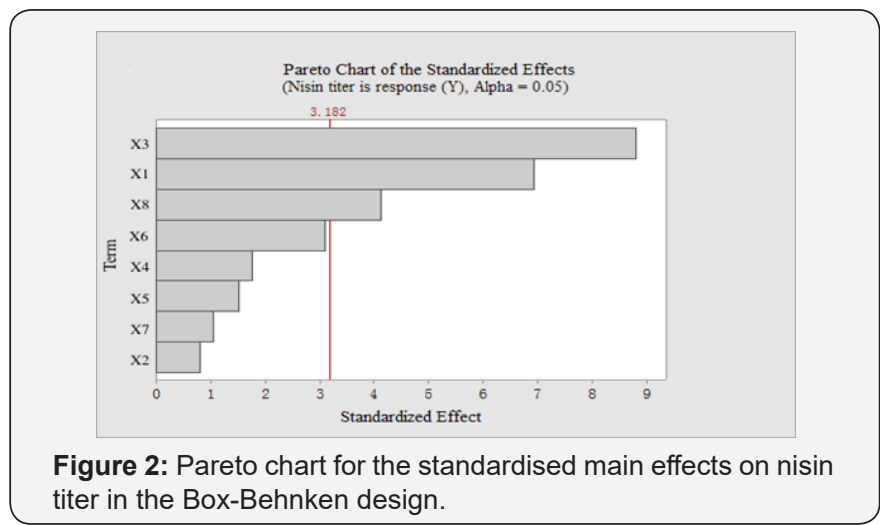

\section{Steepest ascent design}

Table 4: The design matrix and experimental results of steepest ascent experiment with nisin titer as response value $(\mathrm{Y})$.

\begin{tabular}{|c|c|c|c|c|}
\hline Run & $\begin{array}{c}\text { X1 (gl- } \\
\mathbf{1}\end{array}$ & $\begin{array}{c}\mathbf{X} \text { (gl- } \\
\mathbf{1})\end{array}$ & $\begin{array}{c}\mathbf{X 8} \text { (gl- } \\
\mathbf{1})\end{array}$ & $\begin{array}{c}\mathbf{y}(\mathbf{I U} \\
\mathbf{m I}-\mathbf{1})\end{array}$ \\
\hline 1 & 15 & 15 & 2 & 2547 \\
\hline 2 & 16.5 & 13 & 2.2 & 2634 \\
\hline 3 & 18 & 11 & 2.4 & 2750 \\
\hline 4 & 19.5 & 9 & 2.6 & 2891 \\
\hline 5 & 21 & 7 & 2.8 & 2786 \\
\hline 6 & 22.5 & 5 & 3 & 2709 \\
\hline
\end{tabular}


In this section, the starting points of the path chosen for experimental design were $1.5 \% \mathrm{X} 1$ (sucrose, w/v), $0.2 \% \mathrm{X} 8$ (Tween-80, w/v) and 1.5\% X3 (CSLP, w/v) according to the results of $\mathrm{PBD}$, and five equally spaced points along the path were then selected by increasing the concentrations of sucrose and Tween-80 and decreasing the concentration of CSLP. The directions of changing the three variables and corresponding nisin titer obtained in these experiments are summarized in Table 4. It is clearly observed that the peak of nisin titer was reached at Run 4 , which indicated that the response value approached the neighborhood of the optimum medium, and this medium was then chosen for the next optimization.

\section{Response surface methodology}

The central point's chosen from the above steepest ascent experiment for experimental design were $1.95 \%$ sucrose $(\mathrm{w} / \mathrm{v})$, $0.26 \%$ Tween-80 (w/v) and 0.9\% CSLP (w/v). The BBD and the corresponding experimental responses were listed in Table 5 and Table 6, respectively. Regression analysis was showed in Table 7 and a second-order polynomial equation fitting the response function was obtained:

Table 5: The coded values and levels of defined variables for BoxBehnken design.

\begin{tabular}{|c|c|c|c|}
\hline \multirow{2}{*}{ Factors } & $\begin{array}{c}\text { Low Level } \\
\mathbf{( - 1 )}\end{array}$ & $\begin{array}{c}\text { Central Point } \\
\mathbf{( 0 )}\end{array}$ & $\begin{array}{c}\text { High Level } \\
\mathbf{( + 1 )}\end{array}$ \\
\cline { 2 - 4 } & 18 & 19.5 & 21 \\
\hline X1 & 7 & 9 & 11 \\
\hline X3 & 2.2 & 2.6 & 3 \\
\hline
\end{tabular}

Table 6: The design matrix and experimental results of Box-Behnken design with nisin titer as response value $(Y)$.

\begin{tabular}{|c|c|c|c|c|}
\hline Run & $\mathbf{X 1}\left(\mathbf{g l}^{-1}\right)$ & $\left.\mathbf{X} \mathbf{3} \mathbf{g l}^{-1}\right)$ & $\mathbf{X 8}\left(\mathbf{g l}^{\mathbf{1}}\right)$ & $\begin{array}{c}\mathbf{Y}(\mathbf{I U} \\
\mathbf{m l}\end{array}$ \\
\hline 1 & -1 & -1 & 0 & 2559 \\
\hline 2 & 1 & -1 & 0 & 2687 \\
\hline 3 & -1 & 1 & 0 & 2622 \\
\hline 4 & 1 & 1 & 0 & 2623 \\
\hline 5 & -1 & 0 & -1 & 2526 \\
\hline 6 & 1 & 0 & -1 & 2504 \\
\hline 7 & -1 & 0 & 1 & 2636 \\
\hline 8 & 1 & 0 & 1 & 2743 \\
\hline 9 & 0 & -1 & -1 & 2466 \\
\hline 10 & 0 & 1 & -1 & 2549 \\
\hline 11 & 0 & -1 & 1 & 2811 \\
\hline 12 & 0 & 1 & 1 & 2782 \\
\hline
\end{tabular}

\begin{tabular}{|c|c|c|c|c|}
\hline 13 & 0 & 0 & 0 & 2889 \\
\hline 14 & 0 & 0 & 0 & 2914 \\
\hline 15 & 0 & 0 & 0 & 2855 \\
\hline
\end{tabular}

Table 7: The regression analysis of Box-Behnken design.

\begin{tabular}{|c|c|c|c|c|}
\hline Term & Coefficient & $\begin{array}{c}\text { Standard } \\
\text { Error }\end{array}$ & t-value & P-value \\
\hline model & 2886 & 24.4 & 118.286 & 0 \\
\hline $\mathrm{X} 1$ & 26.75 & 14.94 & 1.79 & 0.133 \\
\hline $\mathrm{X} 3$ & 6.63 & 14.94 & 0.443 & 0.676 \\
\hline $\mathrm{X} 8$ & 115.88 & 14.94 & 7.756 & $0.001^{* * *}$ \\
\hline $\mathrm{X} 1 * \mathrm{X} 1$ & -156.5 & 21.99 & -7.116 & $0.001^{* * *}$ \\
\hline $\mathrm{X} 3 * \mathrm{X} 3$ & -106.75 & 21.99 & -4.854 & $0.005^{* * *}$ \\
\hline $\mathrm{X} 8 * \mathrm{X} 8$ & -127.25 & 21.99 & -5.786 & $0.002^{* * *}$ \\
\hline $\mathrm{X} 1 * \mathrm{X} 3$ & -31.75 & 21.13 & -1.503 & 0.193 \\
\hline $\mathrm{X} 1 * \mathrm{X} 8$ & 32.25 & 21.13 & 1.526 & 0.187 \\
\hline $\mathrm{X} 3 * \mathrm{X} 8$ & -28 & 21.13 & -1.325 & 0.242 \\
\hline
\end{tabular}

Asterisk (*) indicates the significance level

$\mathrm{R} 2=97.04 \%, \mathrm{R} 2(\operatorname{adj})=91.70 \%$

$\mathrm{Y}=2886+26.75 \mathrm{X} 1+6.63 \mathrm{X} 3+115.88 \mathrm{X} 8-156.5 \times 1^{2}-106.75 \mathrm{X}^{2}-$ 127.25X8 $2-31.75 \mathrm{X} 1 \mathrm{X} 3+32.25 \mathrm{X} 1 \mathrm{X} 8-28 \mathrm{X} \times 8(2)$

In this model, the t-test and P-values were used to identify the effect of each factor on nisin titer. The terms, $\mathrm{X} 8, \mathrm{X} 1^{2}, \mathrm{X} 3^{2}$ and $\mathrm{X} 8^{2}$, had significant effects on nisin titer $(\mathrm{P}<0.05)$, while the other terms showed a less obvious influence on nisin titer (P $>0.05$ ). The fitness of the regression equation was examined by the coefficient of determination $\mathrm{R}^{2}$, which was calculated to be 0.9704 , indicating that $97.04 \%$ of the variability in the responses could be explained by the model. Also the adjusted determination coefficient (Adj $\mathrm{R}^{2}=91.70 \%$ ) was very high to support a very reliable correlation of the model. Hence, it was reasonable to use the regression model to analyze the variables for the experimental responses.

The effects of sucrose, CSLP and Tween-80 on nisin production were also investigated by the 3 -dimensional response surface. In Figure 3, the curves with obvious convexity of the sucrose, CSLP and Tween-80 against nisin titer could explain the results of the statistical analyses. It could be calculated from the regression equation ( 3 ) and the curves that nisin production reached its maximum at a combination of the coded levels 0.140 (X1), - 0.053 (X3), and 0.479 (X8). Accordingly, the fitted model predicted a maximum response value of nisin titer $\left(2916 \mathrm{IUml}^{-}\right.$ $\left.{ }^{1}\right)$ at the optimal concentrations of $1.97 \%(\mathrm{w} / \mathrm{v})$ sucrose, $0.89 \%$ $(\mathrm{w} / \mathrm{v})$ CSLP, $1 \%(\mathrm{w} / \mathrm{v})$ yeast extract, $0.5 \%(\mathrm{w} / \mathrm{v}) \mathrm{KH}_{2} \mathrm{PO}_{4}, 0.2 \%$ (w/v) $\mathrm{NaCl}, 0.03 \%(\mathrm{w} / \mathrm{v}) \mathrm{MgSO} 4 \cdot 7 \mathrm{H}_{2} \mathrm{O}, 0.5 \%$ (w/v) $\mathrm{CaCO}_{3}$ and $0.28 \%(w / v)$ Tween-80. 


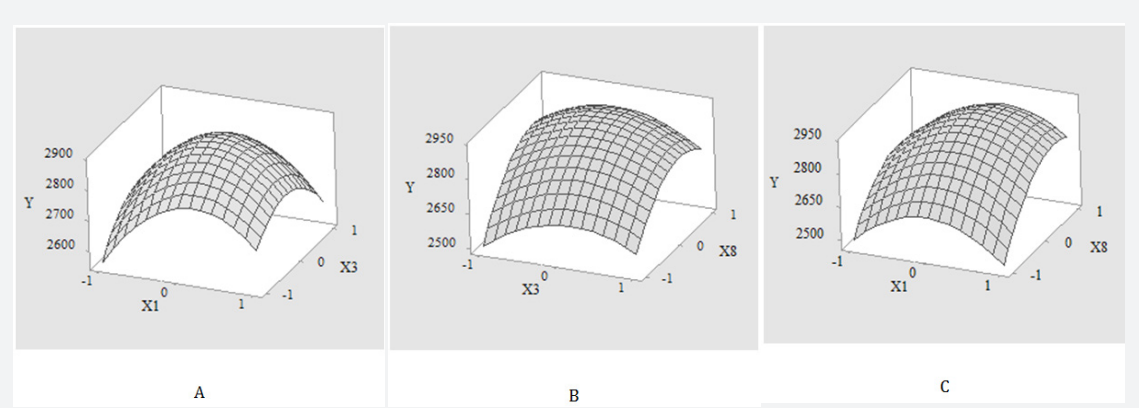

Figure 3: Response surface plots of the interactions of $X 1$ (sucrose) and X3 (CSLP) (A), X1 (sucrose) and X8(Tween-80); (B), X3 (CSLP) and $X 8$ (Tween-80); (C) on nisin production $(Y)$. The coded values of the independent variables were obtained according to the equation (1): $\mathrm{X} 1=(\mathrm{x} 1-19.5) / 1.5 ; \mathrm{X} 3=(\mathrm{x} 3-9) / 2 ; \mathrm{X} 8=(\mathrm{x} 8-2.6) / 0.4$.

\section{Validation of the optimal medium}

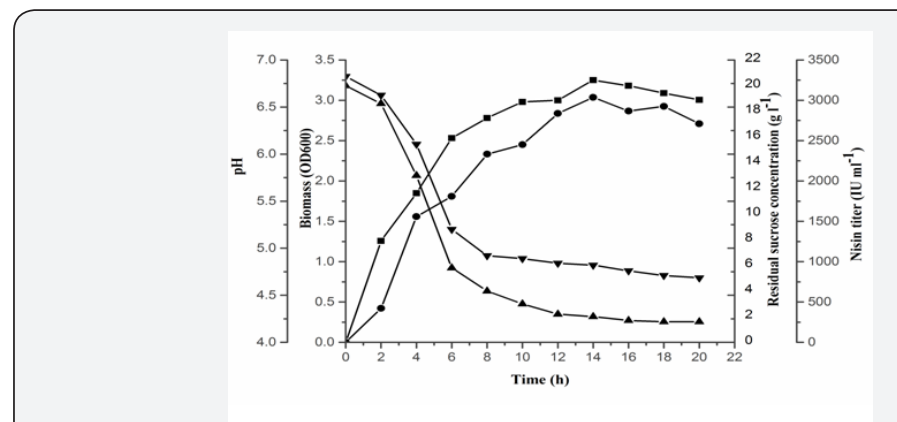

A

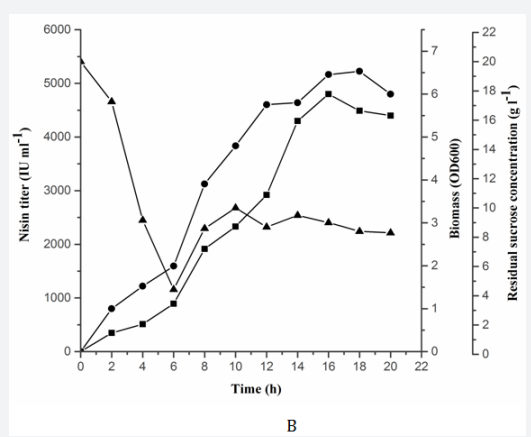

Figure 4: Kinetics analysis of nisin production by $L$. lactis $E 15$ in batch fermentation system using the optimal medium (A) and in fed-batch fermentation system using the optimal medium and constant $\mathrm{pH}$ (6.5); (B). The symbols were used: $\mathrm{pH}$ (solid inverted triangle), Biomass (OD600) (solid square), Residual sucrose concentration (solid triangle), and nisin titer (solid circle).

In order to confirm the validity of the model equation for predicting maximum nisin production, the validation experiment was performed in triplicate under the optimal condition for nisin production by batch fermentation. The observed experimental data was illustrated in Figure 4A. The highest average nisin yield of $3037 \mathrm{IU} \mathrm{ml} \mathrm{m}^{-1}$ was obtained at $14 \mathrm{~h}$, which was in good agreement with the model predicted maximum value of 2916 $\mathrm{IU} \mathrm{ml}{ }^{-1}$ within the range of the permitted errors $(\mathrm{P}>0.05)$ and almost increased by $52 \%$ compared with that in the initial medium (1992IU ml-1 ${ }^{-1}$ Figure 1). This result confirmed that the optimized medium favored the production of nisin.

Simultaneously, the kinetics analysis showed that the consumption of sucrose, production of nisin and lactic acid in the lag phase $(0-2 \mathrm{~h})$ were very slow, while in exponential growth phase, the nisin titer and OD600 increased quickly and reached a maximum value of $3036.59 \mathrm{IU} \mathrm{ml} \mathrm{I}^{-1}$ and 3.0 at $14 \mathrm{~h}$, respectively. And the sucrose was rapidly consumed and decreased to a low level of $2 \mathrm{~g} \mathrm{l}^{-1}$ after $14 \mathrm{~h}$. It has been reported that nisin production shows primary metabolite kinetics and the maximum nisin production is related to biomass formation of the producers $[13,16,29]$. However, the batch fermentation produced a lower biomass after $14 \mathrm{~h}$, which might be attributed to a low sucrose level and acid inhibition (low pH stress) accumulated by lactic acid. The effect of $\mathrm{pH}$ on the growth and nisin production of lactic acid bacteria was well investigated $[16,30]$, so $\mathrm{pH}$ regulation of nisin biosynthesis must be taken into consideration. And the peak value of nisin titer dropped significantly after $14 \mathrm{~h}$, this might be due to the proteolytic inactivation, protein aggregation and the adsorption of nisin molecules to the cell surface of the producer cells [31,32].

\section{Fed-batch fermentations}

Additionally, different results of the fed-batch fermentation in 1.0-L fermenter by the above strategy described in Materials and Methods were shown in Figure 4B. The biomass curve exhibited a greater biomass and a longer exponential growth phase compared with that in the batch fermentation, and the cell growth (OD600) reached its maximum of approximately 6.0 at $16 \mathrm{~h}$. The production of nisin raised with the rapid growth of the producer cells during the exponential growth phase by manual sucrose control, and the maximum nisin titer of $5370 \mathrm{IU} \mathrm{ml}^{-1}$ was obtained after $16 \mathrm{~h}$. But, the cell growth and sucrose consumption appeared to be terminated owing to the end-product inhibition. Thus, compared with the batch culture, a greater biomass and a longer exponential growth phase caused by the fed-batch fermentation strategy combined sucrose control and constant $\mathrm{pH}$ could favor the cell growth and accumulation of nisin under the optimal medium condition [33-35].

\section{Conclusion}

In this study, the modified medium containing CSLP instead of peptone as nitrogen source was positively investigated 


\section{Advances in Biotechnology \& Microbiology}

for further optimization through the statistically designed optimization. We obtained the final optimal medium for nisin production composed of $1.97 \%(\mathrm{w} / \mathrm{v})$ sucrose, $0.89 \%(\mathrm{w} / \mathrm{v})$ CSLP, $1 \%(\mathrm{w} / \mathrm{v})$ yeast extract, $0.5 \%(\mathrm{w} / \mathrm{v}) \mathrm{KH}_{2} \mathrm{PO}_{4}, 0.2 \%(\mathrm{w} / \mathrm{v})$ $\mathrm{NaCl}, 0.03 \%(\mathrm{w} / \mathrm{v}) \mathrm{MgSO}_{4} \cdot 7 \mathrm{H} 2 \mathrm{O}, 0.5 \%(\mathrm{w} / \mathrm{v}) \mathrm{CaCO}_{3}$ and $0.28 \%$ $(\mathrm{w} / \mathrm{v})$ Tween-80 (X3). The yield of nisin produced by L. lactis E15 in batch fermentation system at $14 \mathrm{~h}$ was increased from an average of 1992 $\mathrm{IU} \mathrm{ml}^{-1}$ to $3037 \mathrm{IU} \mathrm{ml} \mathrm{m}^{-1}$, and the optimized condition was used for constant $\mathrm{pH}$ fermentation in fed-batch fermentation system, where a maximum activity of $5370 \mathrm{IU} \mathrm{ml}^{-1}$ was achieved at pH 6.5 after $16 \mathrm{~h}$. Compared with the initial medium, the substitution of CSLP as nitrogen source successfully produces an optimized medium for nisin production by L. lactis E15, which might reduce the fermentation cost. Therefore, this study provides a potential strategy for increasing nisin yield in large-scale industrial production.

\section{References}

1. Chopin M C, Chopin A, Rouault A, Galleron N (1989) Insertion and amplification of foreign genes in the Lactococcuslactis sub sp. lactischromosome. Appl Environ Microbiol 55(7): 1769-1774.

2. Madigan M, Martinko J (2005) Brock Biology of Microorganisms, $\left(11^{\text {th }}\right.$ edn), p. 1-63.

3. Hurst A (1981) Nisin. Advances in applied microbiology 27: 85-123.

4. Cheigh CI, Pyun YR (2005) Nisin biosynthesis and its properties. J Biotechnology Letters 27(21): 1641-1648.

5. Hurst A, Hoover DG (1993) Nisin. In: Davidson PM, Branen AL, (Eds.), Antimicrobials in foods. ( $2^{\text {nd }}$ edn), Marcel Dekker Inc., New York, USA, pp. 369-394.

6. Delves-Broughton J, Blackburn P, Evans R, and Hugenholtz J (1996) Applications of the bacteriocin, nisin. Antonie van Leeuwenhoek 69(2): 193-202

7. Severina E, Severin A, Tomasz A (1998) Antibacterial efficacy of nisin against multidrug-resistant Gram-positive pathogens. J AntimicrobChemother 41(3): 341-347.

8. Sheldon BW, Schuman JD (1996) Thermal and biological treatments to control psychrotrophic pathogens. Poult Sci 75(9): 1126-1132.

9. Gordon YJ, Romanowski EG, McDermott AM (2005) A review of antimicrobial peptides and their therapeutic potential as anti-infective drugs. Curr Eye Res 30(7): 505-515.

10. De Kwaadsteniet M, Doeschate KT, Dicks LMT (2009) Nisin F in the treatment of respiratory tract infections caused by Staphylococcus aureus. Letters in applied microbiology 48(1): 65-70.

11. Tong Zhongchun, Ni Longxing, Ling Junqi (2014) Antibacterial peptide nisin: A potential role in the inhibition of oral pathogenic bacteria. Peptides 60: 32-40.

12. Aranha C, Gupta S, Reddy KVR (2004) Contraceptive efficacy of antimicrobial peptide nisin: in vitro and in vivo studies. Contraception 69(4): 333-338 .

13. De Vuyst L, Vandamme EJ (1992) Influence of the carbon source on nisin production in Lactococcuslactis subsp. lactis batch fermentations. J Gen Microbiol 138(3): 571-578.

14. De Vuyst L, Vandamme EJ (1993) Influence of the phosphorus and nitrogen source on nisin production in Lactococcuslactis subsp. lactis batch fermentation using acomplex medium. Appl Microbio Biotechnol 40(1): 17-22.
15. De Vuyst L (1995) Nutritional factors affecting nisin production by Lactococcuslactissub sp. lactis NIZO 22186 in a synthetic medium. J Appl Bacteriol 78(1): 28-33.

16. Matsusaki H, Endo N, Sonomoto K (1996) LantibioticNisin Z fermentative production by Lactococcuslactis IO-1: relationship between production of the lantibiotic and lactate and cell growth. Appl Microbiol Biotechnol 45(1-2): 36-40.

17. Jozala AF, de LencastreNovaes LC, Olivia C, Moraes D, Penna TCV (2005) Increase of nisin production by Lactococcuslactisin different media. Afr J Biotechnol 4(3): 262-265.

18. Hao Y, Zhang L, Sun J (2013) Study on 2, 3-Butanediol Production by SerratiaMarcescens G1 Using Corn Steep Liquor Powder and Ammonium Dibasic Phosphate. Chemistry \& Bioengineering 6: 011.

19.Xi YL, Chen KQ, Dai WY, Ma JF, Zhang M, et al. (2013) Succinic acid production by Actinobacillussuccinogenes NJ113 using corn steep liquor powder as nitrogen source. Bioresource technology 136: 775779 .

20. Ooijkaas LP, Wilkinson EC, Tramper J, Buitelaar RM (1999) Medium optimization for spore production of Coniothyriumminitans using statistically-based experimental designs. Biotechnol Bioeng 64(1): 92100.

21. Kiran, KR, Karanth NG, Divakar S (1999) Preparation of stearoyl lactic acid ester catalyzed by lipases from Rhizomucomiehei and porcine pancreas optimization using response surface methodology. Appl. Microbiol. Biotechnol 52(4): 579-584.

22. Kong Q He G, Chen Q, Chen F (2004) Optimization of medium composition for cultivating Clostridium butyricum with response surface methodology. J Food Sci 69(7): 163-8.

23. Zhang L, Yang Y, Sun J, Shen Y, Wei D, et al. (2010) Microbial production of 2,3-butanediol by a mutagenized strain of Serratiamarcescens H30. Bioresource Technology 101(6): 1961-1967.

24. Zhou XX, Pan Y J, Wang Y B (2008) Optimization of medium composition for nisin fermentation with response surface methodology. Journal of food science 73(6): M245-M249.

25. Li C, Bai J, Cai Z, Ouyang F (2002) Optimization of a cultural medium for bacteriocin production byLactococcuslactis using response surface methodology J Biotechnol 93(1): 27-34.

26. Liu C, Hu B, Chen S, Glass RW (2007) Utilization of condensed distillers solubles as nutrient supplement for production of nisin and lactic acid from whey. Appl BiochemBiotechnol 137-140(1-12): 875-884.

27. Simşek O, Akkoç N, Con AH, Ozçelik F, Saris PE, et al. (2009) Continuous nisin production with bioengineered Lactococcuslactis strains. J Ind Microbiol Biotechnol 36(6): 863-871.

28. Huot E, Barrena-Gonzalez C, Petitdemange H (1996) Tween 80 effect on bacteriocin synthesis by Lactococcuslactis sub sp. cremoris J46. Letters in applied microbiology 22(4): 307-310.

29. Kim WS, Hall RJ, Dunn NW (1997) The effect of nisin concentration and nutrient depletion on nisin production of Lactococcuslactis. Appl Microbiol Biotechnol 48(4): 449-453.

30. Pongtharangkul T, Demirci A (2006) Effects of $\mathrm{pH}$ profiles on nisin production in biofilm reactor. Applied microbiology and biotechnology 71(6): 804-811.

31. Wu Z, Wang L, Jing Y, Li X, Zhao Y (2009) Variable volume fed-batch fermentation for nisin production by Lactococcuslactis subsp. lactis W28. Applied biochemistry and biotechnology 152(3): 372-382.

32. Wentao Kon, Ting Lu (2014) Cloning and optimization of a nisinbiosynthesis pathway for bacteriocinharvest. ACS Synthetic Biology 3(7): 439-445. 
33. Haina Li (2011) Screening of high yield nisin-producing strains and optimization of its fermentation conditions. Dissertation. Shandong University.

34. Hampikyan H (2009) Efficacy of nisin against Staphylococcus aureus in experimentally contaminated sucuk, a Turkish-type fermented sausage. J Food Prot 72(8): 1739-1743.
35. Periago PM, Moezelaar R (2001) Combined effect of nisin and carvacrol at differrent $\mathrm{pH}$ and temperature levels on the viability of different strains of Bacillus cereus. Int J Food Microbiol 68(1-2): 141-148.
This work is licensed under Creative

Commons Attribution 4.0 Licens

DOI: 10.19080/AIBM.2017.02.555585
Your next submission with Juniper Publishers will reach you the below assets

- Quality Editorial service

- Swift Peer Review

- Reprints availability

- E-prints Service

- Manuscript Podcast for convenient understanding

- Global attainment for your research

- Manuscript accessibility in different formats ( Pdf, E-pub, Full Text, Audio)

- Unceasing customer service

Track the below URL for one-step submission https://juniperpublishers.com/online-submission.php 